\title{
THE WORLD OF EUROPEAN INFORMATION
}

\section{AN INSTITUTIONAL AND RELATIONAL GENESIS OF THE EU PUBLIC SPHERE PHILIPPE ALDRIN*}

Chapter 5 from the book: GEORGAKAKIS Didier and ROWELL Jay, eds., The Field of Eurocracy. Mapping the EU Staff and Professionals, London, Palgrave Macmillan ("European Administrative Governance" Series), 2013

$\mathrm{N}$ either the EU communication policy nor the criticism it is subject to are new. Born with the integration process itself, the question of Community communication can be traced back to the 1950s, when the High Authority sought to develop the 'public relations' of the ECSC (European Coal and Steel Community) '. A first report by the European Parliament devoted to the 'information problem' of the European community project was published in the 1950s (Carboni, 1957). Although this question was from the inception an important issue in inter-institutional debates (the Parliamentary Assembly adopted resolutions on the information-communication policy in 1960, 1962, 1972 and 1986), it was only from the 1980s onwards that information-communication policy became the subject of recurrent controversy, particularly around the themes relative to the excessive power of the Commission and the 'democratic deficit' of Europe until then synonymous with parliamentary impotence (Marquand, 1979). Sporadically, crisis after crisis, and controversy after controversy, the paradigms on which the conceptual frameworks of European Communication were based shifted. First of all, the 'challenges' facing European leaders in terms of opinion and the media were not the same in 1952 as they were in 1992 or today. From the end of the 1990s onwards, the diffusionist approach to communication that prevailed in the first decades of the European project, based on a pedagogy instrumentalizing 'opinion makers' as relays of information (Aldrin, 2009), progressively lost ground to a more procedural conception on the one hand where communication, integrated upstream of policy formulation, mobilized dialogue and on deliberative democracy mechanisms on the other hand seeking to give substance to the 'governance' framework (Georgakakis, De Lassalle, 2007a)².

(*) Professor at Sciences Po Aix (http://www.sciencespo-aix.fr/media/CV_Aldrin.pdf) 1 In 1955, the High Authority commissioned Brose and Elvinger, a professional agency, to produce a report on the development of 'public relations' (Brose, Elvinger, 1955).

2 We must put this evolution in perspective and highlight the permanence, in EU institutions, of the diffusionist paradigm, through the continued existence of the four hundred 'Europe Direct' centers housed by the various partners (universities, local authorities, chambers of commerce). 
But how can one better understand, beyond this paradigmatic shift, the concrete functioning of and transformations in European communication? On this question, the academic literature contains a peculiar bias. Most authors start from the end of the process and focus on the effects of the EU's communication policy and, ultimately, on its supposed inefficiency, in order to identify the causes. Attempting to diagnose Europe's inability to address the communication 'challenge', observers tend to focus on identifying the 'strategic errors' that could explain its 'failure' (Dacheux, 2004). Though the inventory of arguments characterizing the successive controversies in the history of EU communication policy probably predisposes to such an interpretation, a more structural approach can help shed some light on the institutionally and sociologically roots of the 'problem'3.

To do so, one must first take into account the transformations resulting from the successive political changes in the European community. With the direct elections of MEPs ${ }^{4}$, citizen behaviour and opinions measured with regular opinion polls (Eurobarometer) - have progressively become the main indicator of the EU's political legitimacy. Since the principles of legitimization of political Europe became aligned with those of any other 'public democracy's, each 'crisis' (low voter turnout, negative referendum) has had a magnifying effect on the EU's 'communication strategy', giving critics the opportunity to express themselves (Kingdon, 1984). But here too, discourses account only imperfectly for the reality of the situations and practices, and even more so for the changes in this reality. Against the impression generated by the steady stream of accusations made by active Eurosceptics, who qualify the EU communication as structurally dysfunctionals, the information-communication mechanism has undergone successive adjustments and experienced objective successes such as the constitution of a substantial press corps in Brussels. As early as Delors' first mandate, 'information policy' was officially renamed 'European communication'. The completion of the Single Market and the new Treaty provisions - including EU citizenship and the second 'pillar' has partly eroded the States resistance to

3 In a sense close to the program defined by F. Bailey: 'We are looking for a level of knowledge of the game which those that play it might not have. It is that which the anthropologist or the Political science specialist seeks to reach. Until s/he gets there, all $s /$ he does is describe what the players themselves know and $s /$ he has not begun to carry out his/her own analysis.' (Bailey, 1971, p.22).

${ }^{4}$ With, in particular, the 1976 reform introducing the election of MEPs by direct universal suffrage and the use of referendums for ratifying new treaties.

5 In this third age of democracy, described by Bernard Manin as dominated by the mass media, the personalization of politics and opinion polls, 'a new elite of communication specialists is replacing political activists and apparatchiks'. (Manin, 1995, p.279)

6 Adopted by MEPs in 1986, at the threshold of a new political age galvanized by the prospect of a Single European Market, the Baget-Bozzo report demanded a 'true European communication policy' using, without limits, all available means and media (European Parliament, 1986). 
Brussels attempts to communicate its 'propaganda' directly to citizens (Foret, 2008, p.63). Thus, in the late 1980s and early 1990s, the EU's information and communication policy asserted itself more openly as a program for the integration of national opinions, even though, as we shall see, this objective had been conceptualized and operationalized much earlier.

But it is the 'nature', scope and horizon of Europe itself that have changed. It is now not only possible but accepted to use proactive rhetoric on strategic communication to serve the European project. The Maastricht moment, marked by voters' unexpected timidity and the recommendations provided in the de Clerca report ${ }^{7}$ accelerated the transformation of the communication apparatus as well as the public justification of this transformation. Commercial communication techniques were used in the 'information effort'. Marketing principles and terminology, as well as the figurative fictions of the general public (the 'European citizen', 'European Youth') became part of the discursive and action repertoires of the Commission (Tumber, 1995). For a long time considered as an artificial institutional posture aimed at making EU action more natural and attractive in the eyes of citizens of the Member States (Memmi, 1991), communication was no longer limited to providing information on Europe. It was embraced as a key instrument for political legitimization. From the 1980s onward, the EU agents most interested in the integration process (Commissioners, Spokespeople, DG X agents) and soon after, other European public affairs professionals (international journalists, members of think tanks, lobbyists, communication consultants) started investing themselves more openly into conquering 'European opinion', as the struggle to win the hearts and minds was constructed as the new frontier and central challenge of political Europe.

To get to the root causes of the 'problem' behind the controversies, one must first examine the factors that have led, in the last decade, to a politicization of debates around the EU communication policy. A steadily declining turnout at the European Parliament elections (1999, 2004, 2009), referendum failures (2001, 2005 and 2008), the avowed Euro-phobia of some national governments: the frequency of 'crises' seems to have spun out of control, bringing an increase in the opportunities for an ever increasing number of European information specialists to publicly question EU policy on this topic. The Santer scandalvmarked a highpoint in the criticism and the beginning of a

7 Facing new criticisms formulated or relayed by the media following the difficult ratification of the Maastricht Treaty, the Commission appointed a group of experts comprising eighty professionals from different fields in 1992 (journalists, academics, artists, advertisers, national and European civil servants). Under the chairmanship of the Belgian MEP Willy de Clerca, the group was given a triple mission: 'Compile a descriptive review of the information and communication policies'; 'provide a diagnosis on the quality of the mechanisms, actions, behaviors and means' and 'formulate strategic recommendations' (Clercq, 1993). 
new stage in the institutional conception of EU communication. The dramatic collective resignation of the Commissioners in 1999 was almost unanimously considered (Meyer, 1999) ${ }^{8}$ as the consequence of the inept management by the Commission of its relations with the press'. Thus, as soon as he was appointed, President Prodi promised the rapid adoption of 'an information strategy' and a complete overhaul of the incriminated services - the Directorate General for communication or DG $X$ - as part of a comprehensive reform of the entire administrative apparatus (Cini, 2002). After dissolving DG $X^{10}$, and setting it up again in 2001 as DG PRESS under parliamentary pressure ${ }^{11}$, the Prodi Commission adopted legislation which sought to define 'a new framework for cooperation' (European Commission, $2001 \mathrm{~b})$ and promote a better 'inter-institutional collaboration' (European Commission 2002b) for the information and communication policy of the EU, in accordance with the governance principles theorized in the 2001 White Paper (European Commission, $2001 \mathrm{~b})$. Confronted with yet another record-low turnout at the European elections of 2004, the Prodi Presidency came to an end amidst renewed criticism of the weaknesses of EU institutional communication (Anderson, McLeod, 2008). As a result, the Barroso College, formed in 2004, appointed the Swedish Commissioner Margot Wallström as the first vice-president in charge of 'institutional relations and communication strategy'. Her mission statement includes the reshaping the EU communication policy. Following the failure of the Constitutional Treaty in 2005, Wallström concentrated attention on the 'professionalization' of the European services (European Commission 2005b), routinely made use of the provisions on participatory democracy (European Commission 2005c) and proposed, in a White Paper published in 2006, a 'true break' from existing political objectives and a modification of the division of labor in the field of European communication (European Commission 2006). The

8 The services in charge of the press and communication were seen as been incapable of coping with the media attention given to the rumors, first, and later by the public scandal triggered by the 'Wise man' report published in early 1999. This interpretation of the 'crisis' and its origins lingers on within the institutions whereas a more sociopolitical approach to these events questions if 'strategic errors' alone were responsible for the crisis (Georgakakis, 2001).

9 Gathered in Helsinki in December 1999, the Heads of State and governments invited the European Commission to 'study the general question of the Union's information policy, including improving coordination with its information offices in the Member States and links with national information offices'.

10 DG $X$ is divided into two broad services: the Spokesperson Service (which inherited the Media and Communication Unit) and the DG for Education and culture (which inherited the opinion surveys and publications portfolios). Breaking with tradition, the President took on the 'Media and Communication' portfolio.

11 This following the European Parliament's adoption, in March 2001, of a 'resolution on the Information and communication strategy of the EU,' stressing that the 'communication policy of the European institutions requires urgent adjustment', and 'noting with concern that the reallocation of responsibilities in the field of information policy is considerably delaying the adoption of decisions in this area'. 
propositions put forward by the Commission were met with open opposition from the Commission's main institutional partners (European Parliament, 2006) ${ }^{12}$. The ensuing debate, which think tanks, information sites and specialized agencies heavily influenced and were largely engaged in, led to a compromise agreement for greater inter-agency cooperation (European Commission 2007; 2008a).

Since the late 1990s, a shared diagnosis has thus ascribed the misfortunes of political Europe to poor management of the media and public opinion. From this perspective, one can get a first understanding of the reasons for the success of this rhetoric of the 'insurmountable' challenge and its corollaries, delay and failure.

We do not situate our analysis within this rhetoric, or to put it differently, we do not use the same framework. The question of the relevance or effectiveness of the EU's communication policy will not be raised here and we shall only examine it as a belief of the actors studied. Rather, our approach is to attempt to analyse the process which constructs European communication (Rowell, Mangenot, 2010). For this purpose, we will endeavour to explore a world at work (Becker, 1988), that of the professionals of European information, with its routines, contingencies and conflicts, in the same way as other worlds of Europe have been studied in their concrete reality (Georgakakis, 2002a; Michel, 2005; other chapters in this volume). When one distances oneself from institutional discourses or from media products to conduct the sociology of their producers, the question of European communication no longer appears as a mere phenomenon of discursive ballistics and comes into view as a universe of multiple and complex interactions. Multiple, firstly because the production and publicization of information on EU activities as well as the interpretations they generate, are the products of the activities of a wide range of actors; and most notably of the agents of EU institutions: policy makers and their staff, the administrative personnel in charge of communication (in Parliament, within the Commission, the Council, and Member States); but also, and increasingly, of private producers of information, discourses and analysis on Europe: journalists, activists of political parties and movements, interest groups, think tanks, and so on. They are complex, too, in that the interactions between 'producers', 'developers' and 'reporters' of European news can not be reduced to purely functional (and sometimes dysfunctional) relationships aimed at informing the public on the 'sensitive and significant' facts, to use an expression borrowed from Molotch and Lester (1981). Indeed, these relationships are caught in tensions and competitions of various kinds.

In order to gain insight into this world of European information coproduction, we aim in this chapter to examine the historical and

12 For more details on the institutional criticisms of the White Paper, (Aldrin, Utard, 2008) 
sociological process structuring a relational and transactional space governed jointly by producers, go-betweens, and mediators of European information, or to put it more simply, to do the sociology of the world of the professionals of the 'EU public sphere'. To make sense of the organization of these transactional games, we will proceed in three stages. We first focus on the agents of the Commission including the DG COMM ${ }^{13}$, who, today as in the past, are in charge of organizing European information, and whose practices as well as discourses convey traces of the organizational sedimentation of EU bureaucracy (Pierson, 1996). We will in particular examine the origins of the organizational stigma attached to these agents. Keeping a historical perspective, we will then seek to re-situate the informationcommunication activities at the heart of the institutional and political tensions characterizing a Europe under construction, this time placing more emphasis on jurisdictional disputes, hierarchical issues and the political heteronomy that impact the manufacturing of European information. Finally, we will study the more contemporary transformations this field has undergone, through the changes in the division of labor, the reallocation of resources ${ }^{14}$ and the reconfiguration of the relations between civil servants, journalists, consultants and experts. Our analys will be structured around pairs of oppositions such as administrative-political, independenceinterdependence, autonomy-heteronomy, permanenceintermittence, hierarchy-fragmentation. The aim of this method of analysis is not to distinguish between different types of information producers, but to uncover the tensions and the logics that make them belong to the same world whose morphology is shaped by an institutionalized system of co-production and is the place from which European affairs are being increasingly managed.

13 By convention, we shall use the current name - DG COMM - to generically designate the European Commission's Directorate General for Communication. Its previous names (DG X between 1967 and 1999; DG Press between 2000 and 2005) will only be used in reference to their precise historical context.

14 The term is not used here in its utilitarian sense. As noted by J. Lagroye, the 'notion of resources only makes sense relationally and relatively: relationally because a resource is what we have that our adversary does not; relatively because a quality or social position is only a resource according to the hierarchy of the qualities and positions recognized by the group' (Lagroye, 2002, p.261). 


\section{'INFORMATION PEOPLE' IN THE EC/EU BUREAUCRACY}

Decisions concerning the distribution of information-related tasks made in the 1950s, have had instituting and institutionalizing effects on the organization of this sector of activity, particularly in terms of hierarchies, monopolies and resources. Although, objectively speaking, they cannot be proved or disproved, the founding myths that inhabit social organizations bring to the surface discourses on the historical foundations and structural mechanisms underpinning the principles of classification of contemporary positions. Like any institution, the EU bureaucracy has its own founding myths of the 'European adventure', with its cohorts of 'crusaders' and 'pioneers'. Such myths are a useful entry point for analyzing the morphology of the positional and relational space in which the agents of EU communication, their know-how and reputation evolve and are perceived. Thus, the reputation that 'information people' acquired within the Commission early on provides the first tangible indications on the objective and structural reasons underlying the internalized principles of hierarchization that continue to this day to guide the EU administration. In opposition to a strategic analysis of 'European Communication', our study reveals that the world of EU information specialists is divided or from the ontset and offers uneven legitimacy resources depending on the actors' mandate and scope of action.

\section{'The DG of the good-for-nothings'}

The way it is told by its past and present protagonists, the history of European information agents is nonetheless a golden legend that mirrors the golden legend of the corps of European civil servants based on the memoires of its 'founders' (Dumoulin, 2007). The intrigue of this story is always the same and makes use of the same idealized narrative figures. First, there were uncertain beginnings during which a small team of committed 'adventurers', galvanized by their faith in Europe, and backed and managed by a handful of courageous and rebellious 'captains', advanced despite political resistance and scepticism. Then, with the success of the integration process, the service started to grow and to lose its pioneering charm but earned its stripes as a professional corps within the EU administration. This replacement of activism by bureaucratic specialization, and of the 'forefathers' genius with the professionalism of the highly qualified graduates of EU competitive examinations is accepted as a natural 
evolution. But there is more, or rather something else, in the etiological myth of the institutional communicators. In the testimonies that they readily give to observers, all the actors who were involved in the early years of the European adventure in communication recall their reputation as 'entertainers' within the nascent administration. In these narratives, the EU civil servants assigned to information missions are depicted as having suffered more, and for longer, than other agents, from a reputation of amateurism ${ }^{15}$. Traditionally, the DG COMM has had the reputation (an unenviable one in a corps known for its high qualification level) as the 'DG of the good-for-nothings', of the 'poets'. In an institutional field celebrating technical, legal or economic skills, the poet or entertainer is seen as involved in literary and otherwise futile tasks.

'The personnel of the communication department are always seen as thoughtless hippies. We, at DG COMM, have a bit of a reputation for being the DG of the good-for-nothings ... It's partly true ... though we don't always mess up everything! Not all of us in any case [laughs]. This is partly true, especially because the other DGs tend to not take us seriously. This does have effects. The up-and-comers and outstanding civil servants generally want to be recruited in the Secretariat-General or in the DG Competition, not with us.' (Interview with agent who spent his ten year career in the DG COMM (first in Brussels and then in the Commission representation in a Member State), February 2008).

One is so repeatedly reminded of this disqualification in discussions within the Commission, both in the in-group (DG COMM agents) and the out-group (agents of the other DGs), that one can consider it as part of the indigenous objectification of the symbolic order of the DGs and, more broadly, as an element of the symbolic hierarchy of the space of the EU administration's positions and jobs. This depreciation is confirmed by the political value Commissioners traditionally attach to DG COMM, but also by the structural analysis of the differential desirability of positions within the Commission administration. With respect to the low political 'value' of the DG COMM, it must be noted that the information and communication portfolio has systematically been allocated to Commissioners as a secondary portfolio (see Appendix 1). In their survey on European Commissioners, J. Joana and A. Smith talk about the poor image that sticks to DG COMM in the successive Colleges, and illustrate their analysis with anecdotes and testimonies of Commissioners and their cabinet members that leave no ambiguity (Joana, Smith, 2002, p. 76, p. 177). They go so far as to claim that 'between 1958 and 1999, the overall responsibility for information within the Commission was always seen as an unrewarding portfolio for a Commissioner and a thankless task for the DG X' (Joana, Smith, 2002, p. 193). Concerning the low level of benefits gained from a position in DG COMM in terms of career

15 The 'pioneers' surrounding Jean Monnet at the ECSC perceived themselves and called themselves the 'missionaries' of Europe (Rabier, 1993, p. 25). 
promotion, the study of high-ranking European officials conducted by M. De Lassalle and D. Georgakakis highlights that the career-boosting effects of working in certain DGs such as the DG Administration and the DG COMM, are more limited than in those of the big 'historical' DGs (Competition, Internal Market, for instance) or cabinets (Stevens, 2001). For this reason, the DGs that provide little European institutional capital (Georgakakis, De Lassalle, 2007b) have low relative value in comparison with the DGs that ambitious elite agents aspire to serve. The low political value of the DG COMM and the low prestige of administrative positions, combine and reinforce each other. The lack of a 'heavyweight' Commissioner or of a Commissioner truly dedicated to communication issues results in a shortage of important missions and major challenges, and consequently a lack of opportunities for agents to be spotted as good candidates for positions in a cabinet, which is the most effective career-booster.

\section{The 'genetic' reasons for the stigma}

The tensions that accompanied the creation of the Joint Press and Information Service (1958-1961), the frequent name changes (DG X, DG PRESS, DG COMM), the elimination of the DG from the Commission's organizational structure between 1999 and 2001, the conflictual relationships with other services (the Spokesperson service, DG $11^{16}$ ), were all symptomatic of the contingent nature of the administrative and political issues that affect this Directorate, and therefore its weak attractiveness in terms of career prospects. But among the reasons that historically explain the stigma, the first lies in the way information and communication missions were distributed at the time of the establishment of the Communities. Following the model of the administrative structure implemented by Jean Monnet in 1952 for the High Authority of the ECSC, the executive heads of the EEC and Euratom appointed a Spokesperson to inform and liaise with the press.

These Spokespersons act as press officers. Their main functions consist in writing press releases, conducting briefings, holding press conferences and ensuring close contact with journalists. In this organizational rationale, the Spokesperson is literally the link between the cabinet and the outside world: their functions are therefore political and in no way administrative. Indeed, though the frontier between the political (the cabinet) and the administrative is often fuzzy in the daily work of the institutions, one can still identify a general distinction: the political is what is 'sensitive' in the political arena (Weber, 2003, p. 119). Sensitivity, defined not materially but relationally

16 In the late 1980s, DG $X$ and DG Internal market waged a fierce turf war over the 'audiovisual policy' portfolio (see below). 
and contextually, can therefore be measured by the degree of (potential or actual) interest it receives from the players in the political game, the press, the mass media and therefore, possibly, public opinion. In this perspective, the job of the Spokesperson of EU executives is sensitive, and consequently explicitly political. This is why, as early as the 1950s, they were considered as informal members of cabinet of the heads of the three Communities (Bastin, 2003, p. 265). But, in order to inform the groups affected by Community decisions and activities, the Spokespersons need staff to write brochures and summary sheets; they need personnel to ensure that EU-related information is disseminated to the Member States. This task - which is more administrative in nature as it is more technical and less sensitive to current events - cannot be carried out by the Spokespersons.

On the initiative of members of the Parliamentary Assembly of the Communities, a Joint Press and Information Service (PIS) of the European Communities ${ }^{17}$ was created in the early 1960s. The work of the PIS focused on 'specific audiences', that is to say groups who were either directly concerned by EU decisions (economic policy makers, farmers, trade unionists), or were intended to relays of a positive image of European integration to a wider audience, and particularly the youth (teachers and academics, for example). Communication by the PIS was clearly distinct from the work of the Spokespersons in that it was directed primarily to audiovisual media services and came in the form of various publications or information disseminated at trade shows and exhibitions in Member States and abroad. Thus, since the early 1960s, a principle of division of tasks within the European institutions crystallized: the PIS produces pamphlets on EU activities and maintains 'public relations' with specific groups while the Spokesperson explains the positions of the Commission on sensitive and important issues.

\section{Textbox 1: The division of information-related tasks within the Commission}

In a comminatory internal service note, Giuseppe Caron, VicePresident of the Commission in charge of information, describes the respective tasks of the Spokesman's Group and of the PIS.

'Following an agreement reached on March 11960 between the presidents of the three Executive bodies, and the decisions made by each Executive, the spokesman Groups shall, from January 1 1961, report for all matters to the Executive Body they are attached to, and no longer to the Joint Press and Information Service. Furthermore, the Commission also approved, during its 114 th meeting held on July 27

17 Faced with a void in communication with regard to the development and decisions made by the Communities, MEPs adopted a resolution in June 1958 advocating the creation of a Joint Press and Information Service. Official Journal, July 261958. 
1960, a definition of the tasks as well as of the structure of its own spokesman's Group, as shown below:

\section{A. the Commission's spokesman's Group}

The Spokesperson must primarily follow in detail the daily activities of the Commission and be able to interpret its politics at all times. The action of information $\mathrm{s} /$ he performs is therefore a short-term, rapid and official one. The task of the Spokespersons Group is one of general rather than technical information...

B. Joint Press and Information Service of the European Communities

The Press and Information Service Executives is common to the executives of the three European Communities. [...] The task of the Service is to ensure information in the long run [...]. In conclusion, I ask that, in compliance with the decisions made by the Commission, the services conduct their relations with the press only through the intermediary of the spokesman's group.'

Excerpts from an internal note 'Tasks and Functions of the Commission' spokesman's Group and coordination of its activities with those of the Joint Press and Information Service of the European Communities.' February 1961, CEAB 2/2930.

Sociologically, this functional distribution of communication-related tasks can be interpreted as an implicit distinction between the noble tasks and the thankless ones, defined in terms of skills (verbal dexterity, political sense, a thorough understanding of technical issues and political affairs...) and of partners routinely involved in each profession. In this regard, Sociology has shown the effects of this principle of the division of labor on representations of the relative prestige of professional groups, with the formation of an elite group whose members are deemed pretentious by the other groups in the same professional environment, groups who, for their part, are associated with more menial tasks (Hughes, 1996). Transposing this framework of professional hierarchies to our context reveals the elitist nature of functions assigned to the Spokespersons (working directly with their Commissioner at the heart of the political game or being on the front line with journalists in the newsroom) and, by contrast, the subordinate and less prestigious position of the PIS staff who write pamphlets, prepare press reviews and spread the European message in public events. 


\section{THE PARADOXICAL MANAGEMENT OF EU INFORMATION-COMMUNICATION}

The institutionalization of this original division of informationcommunication tasks partly explains its sensitivity to conflicts opposing the directorates of the Commission but also to the tensions between the Commission, Parliament and national governments. We shall see now that the institutionalization of the Spokesperson was not the only obstacle to the efforts made by the DG COMM agents to impose it as the EU's administrative center for information and communication activities. The specialized services of the other DGs and EU institutions have also contributed to fragmenting communication related work, just as differences between the leaders of a European political arena have been transformed by the deepening process of integration and the entry of the new Member States.

\section{Institutionalizing fragmentation}

At the time of the merger of the executive bodies, the 'interexecutive' structure (1965-1967) responsible for reorganizing the services chose to redefine the hierarchy of the functions for the agents in charge of relations with the press and public opinion. Thus, the PIS became a Directorate General (DG X) of the unified Commission. In the meantime, a unique Spokesperson Service was created and prolonged the Spokesperson Group in place since 1958 within the EEC. The relations with the press were therefore officially split into two distinct areas: the Spokesperson Service, headed by Bino Olivi, was in charge of the accredited press in Brussels. DG $X$ managed relations with the non-accredited press, therefore mostly with the regional press of the Member States. This functional and territorial division fostered lasting rivalry, embodied in the opposition between the leaders of the DG $X$ and those of the SPS; an opposition which its own protagonists J.-R. Rabier and B. Olivi, turned into a legend and which has made the reconciliation of the two services impossible ${ }^{18}$.

18 The SPS and DG $X$ were headed by the same person only three times: R. Ruggiero (1977-1982) led both services after President Jenkins merged the SPS into the DG X; J. Faull (2001) carried out this double responsibility during the transitional period of recreation of the DG X by President Prodi; C. Le Bail was head of the SPS and DirectorGeneral of the DG COMM during the long process of development of the DG's organizational chart (November 2004 to November 2005) during the installation of the Barroso Commission. 


\section{Textbox 2: Nothing personal...}

The dispute between J.-R Rabier and B. Olivi symbolize the tensions between spokespersons and the communicators in the EU bureaucracy.

J. R. Rabier, a former French civil servant at the Plan Commission, joined Jean Monnet in Luxembourg in 1954 and became Chief of Staff of the President of the ECSC High Authority. In 1960, this Catholic personalist and graduate in Political science was appointed Director-General of the PIS and remained at this post until the PIS became DG X in 1967. He was re-appointed Director-General of the DG X in 1970 but was replaced by a high ranking Irish official when the Directorate was expanded in 1973.

B. Olivi was an Italian civil servant and law graduate appointed in 1960 to work with Commissioner Giuseppe Caron (whose mandate included information) as Deputy Head of Cabinet. When, in 1962, a new EEC Commission Spokesperson was to be appointed, Caron recommended his collaborator. Olivi held this position until 1977 and implemented the Commission Press Room system based on the accreditation mechanism, the 'Midday Express' and a 'code' for the relations between the Commission and the press (see below).

In interviews with a team of historians led by Michel Dumoulin, Rabier, Olivi and also some of their former collaborators (Paul Collowald, Colette Le Bail, Max Konsthamm Manuel Santarelli) described at length the various episodes of the dual (Oral History Project, the Historical Archives of the EU, European University Institute, Florence). About the respective profiles of the two heads of EU information affairs and their relationship in the 1960s, M. Santarelli volunteered the following interpretation: 'There were power struggles [...] but never any personal rivalry between them: they had different views on what needed to be done, not about the goal of European action, but about the means of achieving it. Rabier was certainly much more engaged, in a radical federalist manner; whereas Olivi, who was a federalist as well as a loyal follower of Spinelli, was less dogmatic and more convinced of the necessity of taking into account national realities and was more wary of the risks for Europe of a rushed supra-nationality.'

The hierarchy between the DG $X$ agents and the Spokesperson is reinforced by the differential relationship to institutional constraints and career prospects. More than one out of two Spokespersons are former journalists who were personally hired by Commissioners (Joana, Smith, 2002) whereas the majority of the DG $X$ agents are civil servants with, in general high longevity in this Directorate General, in which promotions are rare because there is little turnover among directors 
and heads of units (see below). With regard to the 'information people', it should be noted that the specialization and professionalism the institution attributes - both objectively and subjectively - solely to the Spokespersons, rest primarily on the internalization of skills acquired in fields of activities (mostly journalism) that lie outside European institutions.

\section{The relative centrality of the central services}

Though the influence of a DG in the EU space is subjectively measured through its reputation, it can, as we have seen, be objectively evaluated using a number of indicators such as the political value it gives a Commissioner's portfolio or the amount of European institutional capital it confers upon its staff. It can also be measured more directly through its ability to impose its functions, the amount of human and financial resources it is allocated or the quality or even the power of external protagonist who support it ${ }^{19}$. If DG COMM has performed the statutory role of a 'central service' at the Berlaymont or in the Commission's representations in the Member States20, its capacity to coordinate EU communication activities has traditionally been restricted. Indeed, ever since the EU administrative mechanisms were implemented, a number of communication agents and services have escaped centralization. It is the case, as we have seen, of spokespersons who serve as press officers to the various Commissioners, directly manage their relations with the correspondents accredited in Brussels, and report directly to the President of the Commission (the head Spokesman is the President's Spokesperson). This is also the case of the communication service staff of each DG whose numbers started to increase in the late 1960s. Their role is to manage, for each DG, their own circuits of public relations with professional groups and national administrations. It is, finally, the case of the press services and communication personnel of the other European institutions, such as the Parliament's DG-Press or the Communications Department of the ECB.

Quantitatively, the number of personnel working for DG COMM increased rapidly. The hundred or so civil servants who moved from the PIS to the DG X, rapidly increased to two hundred agents. In 1972, a parliamentary report indicated 215 civil servants and 71 'other

19 The 'coalitions of causes', partly reinforced by support from outside the institutions, have non negligible effects on the frameworks of public policies and the nature of their instruments (Sabatier, 1998).

20 The staff in the Commission's representations located in the capital cities of the Member States are placed under the authority of DG COMM. These decentralized services used to be called press and information external offices. J. Delors wished to change their name and give them a more diplomatic function, hence the reform. 
agents'. Today, almost one thousand staff work for DG COMM ${ }^{21}$, which is more than the average number of agents per DG (around 600). But this figure needs to be put into perspective by taking into account the situation in other DGs: Over 1,000 agents in DG Agriculture, Energy, Transport, Business and Industry and around 2,000 in DG Research. The figure becomes even less impressive when one takes into account the fact that ninety of these agents report to the spokesperson Service and that over five hundred work in the Representations in the Member States. Furthermore, the communication services of some DGs are substantial. In the 'historic' DGs, we can observe the presence of sizeable teams structured into true communication services. A good illustration is Unit R4 for Communication and Information in DG ECFIN which employs 25 agents, or Unit 1 of DG Competition which comprises sixteen agents, or Unit A4 for internal and external communication of DG Internal Market and Services, numbering over 30 agents.

These communication services have no hierarchical relationship with DG COMM. They are allocated their own budgets and operate under the authority of their Director-General, who, in turn reports to the Commissioner in charge of the DG. Thus, the campaign for the launch of the Euro in 2002, which, as a result of its success, has become a benchmark campaign for the Commission, was initiated and managed by the Commissioner for Economic, Monetary and Financial affairs, Yves-Thibault de Silguy, with the support of its own communication services ${ }^{22}$. But this type of communication work is in no way limited to such high profile and 'general public' campaigns unanimously backed by all EU institutions. It is mostly used as an instrument in power relationship between the services or institutions, as is illustrated by the following interview extract.

In the Commission, as in most DGs, there wasn't a highly developed communication culture. For the line managers of my generation (28 years seniority in the Commission), communication was kind of an obscure issue, an additional problem. We were concerned about votes in Parliament and in the Council. There are several reasons for this. The first is we didn't need to do any marketing: the interest is ipso facto self-evident. And for us, there was the Big Bang of the internal market completion. Without much professionalism, with little resources, we started doing communication work. But our problem is not only communication with businesses. It's not structured clearly enough but it does exist. It always has. The problem is that when a service prepares

21 This figure is based on the Commission's organizational charts of 2008 and indicates that there has been a slight rise since the 1990s. In 1997-1998, an internal survey by the Commision estimated that the staff serving information-communication related functions was equivalent to 935 person/years. See DECODE report (DEcoder la COmmission de Demain), 1998. The latest 'Human Resources Report' (2009) indicates that 1023 staff are allocated to 'information, communication and publication' tasks, representing 3 per cent of the Commission's employees.

22 The commission allocated over 200 million $€$ per year for this campaign in 1998 and 1999. ECFIN/R/4/2002/04 report, (July) 2003. 
an action or a policy, we know that each institution is going to look after its own interest. We know now that we need to win over public opinion and the media to be able to win the inter-institutional battle. The political generates too much disturbance. Look at the Bolkenstein directive initially ... and how it ended up. Same thing with the new public procurement directives. A few hundred amendments were made and some are contradictory. That's the problem. In its infinite wisdom [smile] Parliament is capable of voting for everything and its opposite. There's been a drift among the politicians who play the technocrat. And if we, of all people, don't communicate, we'll lose the battle. (Interview with a top civil servant of DG Internal market and services, November 2007)

For this reason, the Commission's (mostly operational) competence to govern communication is a politically sensitive issue that recurrently arises between the main institutions of the EU - whether it is deemed responsible for its failures or suspected by MEPs or national governments of spreading its own message - 'propaganda' - directly to the publics of the Member States. In this perspective, the position and legitimacy of the DG COMM's agents within the world of EU communication vary according to the political circumstances and are subject to the influence of the Commission in inter-institutional relations. Just as we observe differences in statutes, missions and symbolic positions between the Spokespersons (appointed by the Commissioners and assigned to politically sensitive missions) and the DG COMM's agents (most of whom are civil servants performing more 'invisible' tasks), we also notice a certain correlation between the profile and relative permanence of this DG's Directors-General and the degree of conflictuality between EU institutions.

Since the creation of DG X in 1967, fourteen Directors-General have succeeded each other. If they all share the characteristics of an internationalized elite (postgraduate degrees, experience abroad, multilingual), a longitudinal examination of their respective careers reveals two distinct profiles: 1) political collaborators, often high ranking civil servants in their country (jurists or diplomats), engaged in politics, who have served in the cabinets of European Commissioners or ministers. These are intermittent agents of the EU administration community. The time they spend serving the EU - under five years on average - is related to that of the political leaders they work for; 2) the 'servants of Europe', who have the status of EU civil servants and have seldom worked in a cabinet and have worked their way up the ranks. These are permanent agents of the EU (over twenty years of service on average) and spend a longer time at the helm of the DG COMM (over five years) than their 'political' counterparts. The presence of the political collaborators at the head of the DG COMM corresponds to periods of high political heteronomy in the EU information and communication apparatus (see Appendix 1). 
But this political heteronomy must not overshadow the equally profound changes related to the emergence of a veritable market of expertise in the field of European information and discourse. Indeed, from the late 1980s onwards, one can observe a change in the economics and the division of labor in the sector, resulting in changes in the principles of co-production and therefore in the interactions between the intra-institutional professionals (DG COMM agents, Spokespersons, specialists of other DGs) and extra-institutional agents. The emergence of new professions in the field of EU information (communication agencies, think tanks and specialized internet web sites) coincided with the assertive development of a space of activity, which remained highly heteronymous but became based on a rationalisation and a greater recognition of specific skills.

\section{THE FIELD OF INFORMATION PROFESSIONALS}

Though the mediocre results recorded by many indicators 23 have led to widespread criticism of the EU's information policy, these debates mask more structural changes in the relations between 'rival partners' in the production of communication. The production of content, analysis, advice and even criticisms about the EU informationcommunication policy has turned into a market in which positions of recognized experts and contracts can be acquired, and in which professional strategies, economic enterprises and individual careers are developing. In theory, the division of labor between the specialized personnel of public institutions and political journalists is clear-cut, but in practice, the frontiers are fuzzy (Accardo, 1995). In addition to the socialization effects generated by the transactional relations characterizing this professional activity, an examination of careers in the 'world of European information' (Bastin, 2003) reveals that the frontiers are extremely porous. News agencies, consultants and polling agencies work permanently and, in some cases exclusively, with EU institutions. Some go on to employment in European institutions (Bastin, 2003, p. 258), while former EU staff members can be found in private organizations specializing in European affairs. This process reveals a diversification of the professions and careers around EU information. But it is even more

23 The recognized indicators of efficiency of communication policy are, among others, the level of electoral mobilization or support expressed by citizens and the intensity of media coverage of EU affairs. 
revealing of the intense circulation of the same cognitive and relational resources within a field of activity whose borders (which extend beyond the institutional boundaries of the EU) and rules have stabilized around two contiguous, but symbolically differentiated areas of professional practice. The first is content production, for the most part subcontractied and the second is strategic analysis, generally offered by specialized organizations claiming to contribute to the production of frameworks of perception, interpretation and transformation of the European communication 'problem'.

\section{Being a journalist in Brussels : towards the normalization of a profession}

Ever since the early years of European integration, journalists were enrolled in various capacities in EU information politics, initially as 'defectors'. At the head of the ECSC, J. Monnet surrounded himself with journalists like Paul Collowald (former correspondent of Le Monde in Strasbourg) or François Duchêne (former correspondent of the Manchester Guardian in Paris), to infuse professional practices and known-how into press-relations. Most Spokespersons were recruited from the ranks of experienced journalists committed to the integrationist cause who drew closer to the entrepreneurs of Europe by reporting on their work (Collowald, 1993). Journalists were also enrolled as mediators in an on-going effort to inform the public about advances made in the integration process. The history of 'Agence Europe' (created in 1952 in Luxembourg, it was relocated to Brussels with the establishment of the EC) and the career of its emblematic founder, Emanuele Gazzo24 show quite well the 'pro-European' leaning (Lelu, 2000) of the first press agencies established in Brussels such as the Agra agency or Europe Information Service - and the importance of financial support from the Commission, taking the form of a self-interested subscription policy. In return for a few dozen subscriptions, the agencies or national newspapers would send a permanent correspondent to Brussels. Finally, journalists served Europe as experts in editorial work as subcontractors or external collaborators. As part of its increasingly massive diffusion of information and communication materials (brochures, fact sheets, newsletters, studies and reports), the Commission thus started, from the late 1960s onwards, to increasingly resort to journalists working freelance.

On a more statutory level, the implementation of an original and sophisticated accreditation system, co-managed with the professional association of international journalists in Brussels (see box below),

24 E. Gazzo was an Italian journalist sent to Luxembourg in the early years of the ECSC. In 1952 he participated in the founding of the 'International Information Europe' agency which later became Agence Europe. A staunch federalist, Gazzo enjoyed the Commission's support (in the form of subscriptions) for a long time. 
created the conditions for the formation of a European press corps in Brussels. By bringing the news media to Brussels to report on a daily basis, the Commission also sought to impose its image of a center from which political impetus was created in the geographically fragmented (Brussels, Strasbourg, Luxembourg and, more recently, Frankfurt) and technically complex political system. This integration of the European landscape by media companies from the various Member States resulted in the emergence of a new profession: the 'European journalist' in Brussels. The presence at the 'Midday briefing' of an increasing number of accredited journalists contributed to the gradual introduction of 'news on Europe's current affairs' (synonymous with EU political affairs) in major media.

\section{Textbox 3: Accredited journalists at the Berlaymont}

In the early 1960s, the Commission established rules governing access to the press room of the Berlaymont building (the Commission's headquarters) and turned the press briefings given by the Commissioners, or most often their Spokespersons, into daily briefings called the 'Midday briefing' or 'Midday express'. Accreditation was comanaged by the Spokesmans Group (headed by B. Olivi from 1962 to 1977) and the International Press Association, representing the permanent correspondents in Brussels. What some have called the 'Olivi system' (Bastin, 2007) rests primarily on the 'daily briefing' concept but also on a number of advantages reserved for accredited journalists such as a temporary guarantee of exclusivity on information collected in the press room. In an interview with Gilles Bastin, B. Olivi justified the daily nature of the briefing in the following way: 'Why? To give journalists as much as possible and to keep a bit of a hold on them, control them a little. Without that, they were scattered all over the house, there were rumours, leaks ... It was a way to serve journalists' (Bastin, 2003, p.74). Following the same rationale, the Europe by Satellite programme (Television news service of the EU) has, since 1995, provided journalists with images, news items and audio-visual material.

From 40 in 1963, the number of accredited journalists with access to the Berlaymont press room had increased to 1300 in 2005 before declining to just under 800 in 2010 according to the IPA (excluding audio-visual technicians). This recent decline indicates a rejection of the 'propagandist' methods of the Commission, which confuses information and communication.

Several signs show that the unanimously integrationist spirit that characterized collaborations between information professionals across institutional boundaries in the 1950s and 60s, has today disappeared. The enlistment of journalists into the EU institutions, based on the European creed and selective affinities is fading. This trend is probably due to this creed having lost some of its mobilizing power, as 
much as to the normalization (or de-differentiation) of the sociological profiles, professional practices and ethics of the journalists ${ }^{25}$. The 'Santer scandal' in particular brutally revealed that the original rationales of collaboration or co-production between journalists and their informants at the Commission had lost their power. In some ways, the outraged reaction of the professional organizations of journalists in Brussels to the Commission's proposal to create its own press agency 26 is revealing of the exhaustion of a system whereby European information was co-produced with the accredited press.

\section{Textbox 4: A codification of the "I on " and " off "}

The 'Santer scandal' caused both sides to reflect on the relations between the Commission and the press. The agreement reached in 1995 between the IPA and the Spokespersons Group which was intended to provide a better regulatory framework for the relations between the two parties and a basis for the code of ethics of journalists reporting on the Commission's activity today serves to specify, in a novel way, the level of 'officiality' of exchanges between journalists and their informants:

'The status of statements made in the Press Room

"On the record": this information can be attributed to the Commission's spokesperson by name. Everything is on-the-record unless otherwise specified;

"Off the record": The information may be attributed to "Commission sources". Information will be given in the press room wherever possible. This obligation should not be regarded as an attempt to limit direct contact with the Spokesman's Service. It is intended to ensure that important information is not mentioned in the press room, but remains confined to small numbers of people with inside knowledge or to journalists specialising in certain areas. EBS transmission will be interrupted manually for "off-the-record" information.

"Background": The information is not attributable.'

Extract from the codification of the agreements between the Spokespersons Service of the European Commission (SPS) and the International Press Association (IPA).

${ }^{25}$ On the basis of a quantitative study of accredited 'careers', G. Bastin has observed a tendency towards a sociological as well as a professional standardization that began in 1980s. He bases this analysis on the existence of the following combined phenomena: a standardization of the presentation of a professional card to access institutional spaces; the shortening of the average duration of the careers of accredited journalists in Brussels; the upward mobility of journalists in this career path; a decrease in the number of situations of pluriactivity. In connection with this development, he also noted a reduced capacity for self-regulate (Bastin, 2003).

26 Proposition presented in the 2006 White Paper as a wish to 'explore the desirability of having an inter-institutional service operating on the basis of professional standards' (European Commission, 2006, p. 10). 
Media coverage of the EU has increased significantly over the last twenty years thanks, in particular, to the rising awareness of EU-related issues in political debates in the different Member States. But political Europe remains a fragmented political space. Its technical, complex and distant nature explains why it remains a peripheral subject in mainstream media which examine it through the prism of national issues (Schlesinger, 2003; Baisnée, Frinaut, 2007). What is more, the EU is virtually ignored by the primary news media of the majority of European citizens: television. The Commission has therefore made several attempts over the last twenty years to encourage better coverage of EU activities such as the EbS, the EU portal, image banks, audio-visual reports, and a European Radio Network. Though these initiatives have had limited effects due to the clear lack of public interest for the political life of the EU27, the explosion of the institutional production of media content has recently re-ignited the anger of accredited journalists. In February 2010, Frans Boogaard, Brussels correspondent of the Algemeen Dagblad and member of the Board of Directors of the API, published on the API website an article entitled 'Brussels deserves its watchdogs' in which he denounced the development of the communication strategy of the Commission:

'With the decreasing presence of journalists, the institutions are adopting an ever more aggressive Public Relations policy, with web-tv, which offers photos and interviews carried out by internal agents, for free. The Commission Representations abroad organize their own press conferences. And contrary to previous practice, almost all briefings, press conferences and public meetings can be followed on the internet. And though the correspondents naturally take full advantage of this - to cover Strasbourg from Brussels for example - the fact remains that some of the media believe that "Brussels" news can be followed from abroad; a belief that fails to see the importance of direct contacts, of experience in the European labyrinth acquired over time, and of the background information.' (www.api-ipa.eu)

This indignation, formulated in a rhetoric which is specifically professional (and therefore devoid of any pro-European creed) confirms, first of all, that a normalisation of the profession of international journalist in Brussels is taking place, and second, that a subcontracting sector specialized in the production of 'European' news content is emerging ${ }^{28}$.

27 This lack of interest has many reasons and explains why television operators avoid the topic of Europe (Baisnée, 2002). On the Euronews experience, see Baisnée, Marchetti, (2000).

28 Examples of this include the Media Consulta Agency (whose Berlin-based parent agency has branches in all Member States) which produces editorial material for DG COMM and other DGs under a framework contract; the Brussels based Mostra agency (with partner agencies in twenty-five Member States), which has conducted 


\section{The economics of expertise in the field of European information}

Because of its decisional complexity, its physical distance, its reputation as an administrative and technical monster mired in its abstruse jargon, the EU has not yet taken concrete shape in the minds of the public (Gaxie, Hubé, Rowell, 2011), and remains a news topic that does 'not sell well' (Marchetti, 2003b). Paul Magnette talks of an 'Orleanist' public space (Magnette, 2003b) to express its limitation to the enlightened elites of Europe (Costa, Magnette, 2007). These conditions governing EU publicity are not foreign to the process of rationalization, which has gradually but profoundly transformed the European information economy. Economy must first of all be understood here in the broad sense as a heuristic metaphor designating the organized exchange of intangible goods on markets (places and techniques of exchange) involving participants with different roles (producers, brokers, buyers) and a system of rules and values. But we refer to economy in the stricter sense as well, meaning the transaction of products or services involving monetary exchanges. As mentioned before, journalists, called upon by the Commission to provide editorial services since the 1950s, created specialized enterprises to offer services tailored to the needs of the institution. Thus, agencies such as the European Research Associates (established in 1979) and later GPlus Europe (see box below) were founded by experienced specialists in European affairs: former accredited journalists, Spokespersons, former civil servants or collaborators who used their European and professional capital in consulting activities. They offer to Commission services their know-how in strategic studies as well as in public relations and press relations. They also negotiate their knowledge of European institutions with lobbyists, private companies and international organizations that deal with the EU or wish to develop their activities in this market.

\section{Textbox 5: EU information markets and careers}

Founded in 2000 by correspondents, former spokesman and senior staff of the Commission, the GPlus Europe consultancy agency describes itself as 'an expert in the mechanisms, policies and actors of the EU.' The firm's website places explicit emphasis on its internal knowledge of the EU machinery: 'The impact of the European Union on the economic and political life - of Europe and the rest of the world - is constantly growing. However, its internal decision-making mechanisms often remain opaque. The GPlus team helps its clients think through their entire approach to the EU and its Member States. And we help them make their voice heard.'(source: www.gpluseurope.com). Private clients include, Alstom, Walmart, Microsoft and Gazprom.

several campaigns promoting European public policies (healthcare, fisheries, fight against discrimination) and produces the content of EuroparlTV, the European Parliament web television channel. 
The trajectory of Peter Guilford, co-founder (with journalist and producer Nigel Gardner) of this consultancy is quite emblematic of a specialization in European affairs based on circulations between EU institutions and the Brussels consulting scene. After covering European affairs for two decades as an accredited journalist working for The Times, he joined the Commission, and became Leon Brittan's Spokesman (Commissioner for Competition), then the media adviser to President Prodi. He left the Commission in 2000 to found GPlus, and was joined by other former Commission advisers and Spokespersons. His collaborators include Philippe Lemaître (former Brussels correspondent for Le Monde), Michael Tscherny (former journalist at Agence Europe), John Wyles (former Brussels correspondent for the Financial Times) and, recently, Bruno Dethomas (a former journalist at Le Monde, President Delors' spokesman at the late 1980s, and holder of several diplomatic functions for the EU).

Through the creation and proliferation of such agencies, and with the development of specialized information websites (such as Euractiv), a process structuring a market of EU information expertise is taking place. The trajectories of the protagonists show that inside experience of EU institutions as well as relations with actors in the Commission constitute a highly sought after professional capital. The flourishing sector of EU public affairs consulting (in 2010, the Euractiv site estimated that there were 10,000 European public affairs consultants in Brussels) explicitly values experience in the Commission services as a foundation for a consulting career. These profiles are also highly prized among Brussels think tanks which, like the Center for European Policy Studies (founded in 1983) and more recently the European Policy Center (also based in Brussels), intend to influence European public policy. Though the work of think tanks present the more esoteric dimension of a highly specialized forward-looking activity with a strategic purpose, it competes with the agencies in Brussels that specialize in providing expert information to economic decision makers (the target of the EIS agency with its newsletter and now its Euro-politics website), lobbyists and institutional circles. Thus, a market of strategic expertise on how to better approach EU policies and how to 'better communicate Europe' has emerged. It is a market in which the functional distinctions between journalists, advisers, experts and lobbyists disappear. The professional competences of those prescribers of perceptual and interpretive frameworks for public policies are convertible and are functional in public institutional spaces as well as in the private sector. The only thing that differentiates them is the nature of their clients. Thus, think tanks operate as very elitist spaces of brokerage and co-production of EU affairs expertise. 


\section{Textbox 6: The small world of EU affairs consultancy}

The Euractiv site perfectly symbolizes the convertibility of the positions and relationships within the field of Eurocracy. Founded in 1998 by a former Commission official and MEP, the Euractiv site has positioned itself as a portal 'to all relevant documents and policy positions' on EU affairs, 'shortening the time to find the right information for EU Actors.' The site produces little content per se, but provides 'LinksDossiers' (a reasoned documentary database of web links) on key issues. Euractiv presents itself as 'an original business model, based on five elements (corporate sponsoring, EurActor membership, EU projects, advertising, and content syndication)'. It is sponsored in part by the EU Commission. In 2006, the Euractiv Foundation presented M. Wallström with its Yellow paper on EU communication policy entitled 'Can EU hear me?' (source: www. Euractive.com).

Brussels think tanks illustrate the multipositionality of EU affairs experts. Combining economic decision makers, senior officials of national and international and academic institutions, they receive financial support from EU institutions, large international companies and private foundations. The Center for European Policy Studies is headed by the German economist Daniel Gros. Its supervisory board, chaired by Peter Sutherland (Goldman Sachs International), is composed of former high-ranking officials or Commissioners (Max Kohnstamm, Allan Larsson), journalists (Paul Gillespie, The Irish Times), and MEPs (Sylvie Goulard, Graham Watson), heads of consultancies (Philippe de Buck, BusinessEurope, John Wyles, GPlus), academics, representatives of other think tanks, NGOs and foundations. High-ranking officials, parliamentarians and Commissioners in office regularly attend seminars (see. www.ceps.eu) and breakfast briefings.

The convertibility of skills and the (sequential or simultaneous) multipositionality of experts have fuelled concerns about the various influences shaping EU decision making. Following a Parliamentary resolution aimed at bringing greater transparency to the activities of lobbyists (Stubb report), the Commission adopted in May 2008 a 'Code of Conduct for Interest Representatives' establishing a voluntary register which lobbyists working in Brussels are invited to join. The code defines 'interest representation activities' as those carried out with the aim to 'inform and influence policy formulation and the decision-making processes of the European institutions'. Let us note however that the activities conducted 'in response to the Commission's direct request, such as ad hoc or regular requests for factual information, data or expertise, invitations to public hearings, or participation in consultative committees or similar bodies' are explicitly exempt. (European Commission, 2008a, p. 4). 


\section{CONCLUSION}

Now at the end of our exploration of the professional worlds of EU information, we hope to have contributed a more sociological understanding of the European communication 'problem'. Placing actors at the center of the investigation, analyzing trajectories, practices and interactions, and avoiding a teleological vision of 'European construction', has allowed us to examine the publicization of political Europe without entering into a normative discussion of its successes and failures. The processes we have studied are governed by a strategic, yet fragmented communication apparatus that disseminates messages to 'multiplier relays' (media, opinion leaders, institutional partners, civil society). Although European issues and the institutional division of labor are still to some degree represented through the prism of the original conceptions and choices, the way European information is produced has changed. It is nowadays shaped by three overlapping trends.

The first pertains to the introduction into the specialized services of the EU of skills and know-how typical of the professional sector of business communication. The dialectic between the outsourcing and insourcing of skills has led to the gradual alignment of internal institutional practices with the methods of communication professionals. Identifying the 'best stories' in drafting fact-sheets by using the SWOT analysis tool used in marketing to evaluate the Strengths, Weaknesses, Opportunities and Threats involved in a product launch, writing a media impact report analyzing the outcome of a press release, an editorial or a Commissioner's visit to a region or setting up an agenda for a communication campaign, are all actions that are nowadays performed with the same tools and methods by EU agents and their sub-contractors. This sharing of a common language and professional tools shows how much institutional culture has changed. Formerly considered as a tool to be implemented after the essential political work of the Commission, information-communication is now built in from the onset and is seen as an essential component of the legitimacy of political action. The main indicator of this evolution has been the recent effort to professionalize the staff of DG $\mathrm{COMM}^{29}$ and rationalize the communication production chain within the institutions ladvance

29 One can cite for example the relation of additional specific positions in the Commission's Representations since 2005, the creation, in 2006-7 of a 'communication master class' or the implementation of the first competitive examination in communications in 2007-8. 
planning, pooling instruments, and reinforcing inter-institutional coordination) $)^{30}$.

The second trend, which prolongs the first, is related to the managerialization of the system of information co-production. European integration has always involved the enlistment of external experts and professionals in its different fields of activity (Robert, Vauchez, 2010). With regard to the services in charge of information and communication, these collaborations, based on elective affinities around the idea of integration and original protocols of the long term public relations programs such as the 'Olivi system', have brought some efficiency to the information system despite its functional fragmentation. This model has undergone a double rationalization in an effort to counteract the centripetal forces of a 'multi-organization' (Cram, 1994) such as the EU institutional system in which the existence of divergent sectoral interests and political visions inevitably leads to a fragmentation of the production of information. Initiatives undertaken in the aftermath of the failed referendums of 2005 and the 2006 White Paper have aimed to impose a more formalized and streamlined framework for inter-institutional discussion ${ }^{31}$. These efforts can be understood as an effort to generalize 'best practices' and principles of dialogue and not as an attempt to hierarchize information and communication functions. More procedural than organizational, the rationalization of this activity is therefore built around protocols through which the agents of the institution manage, in more depersonalized relationships, intermittent workers (freelance employees, contractual staff, interns) and external service providers executing tasks for the $\mathrm{EU}^{32}$.

The third trend has to do with the standardization of how EU elites approach the 'issue' of the publicization of political Europe. Considered until recently as a problem of didactics (helping the

30 This is illustrated by a series of changes initiated by the Commission after June 2005 , such as the re-shaping of the DG COMM's central organizational chart, the reinforcement of the communication teams in Brussels and in the Representations, the development of EuropeDirect and local information networks and relays, or the reshaping of the Europa portal.

31 The rejection by the Parliament (EuropeanParliament, 2006) and the other representative bodies (EESC, 2006) of the proposals in the 2006 White Paper recommending the transformation of communication into a true common policy (European Commission, 2006, p. 4) resulted in the strengthening of inter-agency coordination through the extension of the prerogatives of the Inter-Institutional Group on Information, or IGI (European Commission, 2007). The IGI is a joint body composed of the Communication directors of the Commission and the EP. Its original mandate was to define and coordinate the priority information actions for campaigns on enlargement and the launch of the Euro.

32 In terms of professional identity, we can note that in the absence of a recognized center or monopoly of expertise, civil servants assigned to these tasks always define themselves in relation to the institutions they serve and not in relation to the missions, technical competency or practical activity that correspond to their function (Dubar, 1997). 
public understand what the EU is about with the idea that the more citizens know about the EU, the more they will identify with it), it is now seen more as a problem (which anyone in power faces) of finding the balance between regulatory action and the necessity to legitimize its foundations, terms and objectives ${ }^{33}$. The succession of crises such as the 'Santer scandal', falling voter turnout, or the referendum failures have caused a shock (De Swaan, 2007). In an entirely new development, Commissioners today publicly comment on the EU's difficult relationship with citizens and on the need for a more participative communication policy. Following the rejection of the Constitutional Treaty, Heads of State and Government invited the Commission to manage a 'period of reflection to enable a broad debate' on the future of the EU (European Council, 2005). Commission agents began making more frequent appearances in their national public arenas. Commissioners have made their visits in the regions a systematic ritual. Behind the deliberative rhetoric and, beyond this multiplication of public appearances aimed at 'giving Europe a human face' (European Commission, 2006, p. 10), the public debate about EU action in the field of information and communication has become less sector specific and a more global issue linked to the theme of 'good governance'. More than in the past, EU Communication has been perceived, described and criticized from the policy angle by journalists, think tanks, national political leaders, whether pro or anti-European. With the installation in 2010, of the Barroso II Commission, DG COMM once again became a common operational service, and communication a secondary mandate for Vice-President Viviane Reding. Though those in power also owe their existence to their appropriation of information (Balandier, 1981), this exercise necessitates, in a democracy, many compromises so as not to appear as an attempt by the institutions of power to manipulate or monopolize political expression. The EU is today caught in the tension typical of modern democracies in that they have to develop strategies, means and tools to reduce uncertainty in a free, pluralistic, and sometimes oppositional public space (Negt, 2007), while avoiding accusations of distilling propaganda ${ }^{34}$.

33 For more details on this classical tension which also opposes elites associated with regulatory work to the masses as recipients of the legitimation effort, (Jobert, Muller, 1987; Duchesne, Muller, 2003).

34 I thank Didier Georgakakis for his meticulous reading of this text and for his comments and suggestions. 


\section{APPENDIX 1}

The political and bureaucratic distribution of positions in information-communication in the European Commission

MANDATE OF THE PRESIDENTS AND THE COMMISSIONERS RESPONSIBLE FOR INFORMATION AND COMMUNICATION

\section{8-1967}

PDT :Walter HALLSTEIN (Jan. 1958 - June 1967)

Administration

INFO-COM : Giuseppe CARON

Vice President(Nov. 1959 - May 1963)

Internal Market, Information (not explicitly

mentioned in the mandate)

Henri ROCHEREAU, Commissioner for Overseas Development (Ad interim between May 1963 and June 1964)

INFO-COM : Guido COLONNA di PALIANO, Vice President

Internal Market, Information (not explicitly mentioned in the mandate)

1967-1970

President: Jean REY (July 1967 - July 1970)

Secretariat-General, Legal Service, Spokesperson

INFO-COM : Albert COPPE, Commissioner for Budgets, Credit, Investment, Press and Information.

\section{0-1973}

President : Franco Maria MALFATTI (July 1970 - March 1972

followed by Sicco MANSHOLT (=> Jan. 1973)

Secretariat-General, Legal Service, Spokespersons

Group

INFO-COM : Albert BORSCHETTE, Commissioner for Competition, Press and Information, Diffusion of information, Regional Policy

\section{3-1977}

President: François-Xavier ORTOLI (Jan. 1973 - Jan.

1977)

Secretariat-General, Legal Service, Spokespersons

Group

INFO-COM : Carlo SCARASCIA MUGNOZZA, Vice

President

Parliamentary Affairs, Environmental Policy,

Protection of Consumer Interest, Transport,

Information

\section{7-1981}

President : Roy JENKINS (Jan. 1977 - Jan. 1981)

Secretariat-General, Legal Service, Spokesperson

Group, Information

\section{1-1985}

President : Gaston THORN (Jan. 1981 - Jan. 1985)

Secretariat-General, Legal Service, Spokesperson
DIRECTORS-GENERAL OF INFORMATION AND COMMUNICATIONS

1960, Creation of the EU Press and Information Service

1960-1967, Jacques René RABIER* Responsible

(*Former chief of cabinet for J. Monnet at the ECSC High Authority)

Jean POORTERMAN, EURATOM spokesperson Louis JANZ, ECSC spokesperson

Giorgio SMOQUINA and later Bino OLIVI, EEC spokesperson (GPP)

1967 -Merger of the Executives

1967 , creation of DG-X and of the Spokesperson Service Louis Janz*

Director-General of the DG-X (* former ECSC spokesperson)

1968-69, Karl Heinz NARJES**, Director-General of the DG-X

(**form Chief of cabinet of W. Hallstein)

B. OLIVI, Director of the Spokesperson Service

P. COLLOWALD, Deputy Director of the Spokesperson Service

1970-1973, Jacques René RABIER

Director-General of the DG-X

1973-1976, Sean RONAN

$$
1973 \text { - First enlargement }
$$

Director-General of the DG-X

1976, Paul COLLOWALD

Director-General of DG-X

1977, President Jenkins merges the Spokesman's Service and DG-X

1977,-1982 Renato RUGGIERO ***

Director-General of DG-X

(*** Spokesperson and later also Chief of Cabinet of President Jenkins)

1982-1987, Franz FROSCHMAIER

Director-General of DG-X 
INFO-COM : Lorenzo NATALI, Vice-President Mediterranean Policy, Enlargement, Information

\section{5-1989}

President : Jacques DELORS (Jan. 1985 - Dec. 1985 Jan. 1989)

Secretariat-General, Legal Service, Spokesperson Service, Joint Interpreting and Conference Service, Security Office, Monetary Matters, Structural Funds

INFO-COM : Carlo RIPA DE MEANA, Commissioner for Institutional Questions, People's Europe, Information and Communication Policy, Culture and Tourism.

\section{9-1993}

President : Jacques DELORS (Jan. 1989 - Jan. 1993)

Secretariat-General, Legal Service, Spokesperson

Service, Joint Interpreting and Conference Service, Security Office, Monetary Matters, Structural Funds, Forward Studies Unit

INFO-COM : Jean DONDELINGER, Commissioner for Audio-visual and Cultural Affairs, Information, People's Europe, Office for Official Publications

\section{3-1995}

President : Jacques DELORS (Jan. 1993 - Jan. 1995)

Secretariat-General, Legal Service, Spokesperson Service, Joint Interpreting and Conference Service, Security Office, Monetary Matters, Structural Funds, Forward Studies Unit, Inspectorate-General, Competition

INFO-COM : João de Deus PINHEIRO, Commissioner in charge of Relations with the European Parliament; Relations with the Member States on Transparency, Communication and Information; Culture and Audiovisual Policy; Office for Official Publications

\section{5-1999}

President : Jacques SANTER (Jan. 1995 - March 1999) Secretariat-General, Legal Service, Security Office, Forward Studies Unit, Inspectorate-General, Joint Interpreting and Conference Service, Spokesperson Service, Monetary matters (with de Silguy), Common Foreign and Security Policy with Van den Broek), Institutional Questions for the IGC (with Oreja)

INFO-COM : Marcelino OREJA, Commissioner for Relations with the European Parliament; Relations with the Member States on Transparency, Communication and Information; Culture and Audiovisual policy; Office for Official Publications, Institutional Questions, Preparation for the 1996 IGC.

\section{9-2004}

President : Romano PRODI (Sept. 1999 - Nov. 2004)

Secretariat-General, Legal Service, Media and

Communication (until 2001) followed by
1987-1990, Manuel SANTARELLI

Director-General of DG-X

1990-1997, Colette FLESCH

Director-General of the DG-X

1997-1999, Spyros PAPPAS

Director of the DG-X

1999-2000, FAULL is Spokesperson, Head of Press and Communication 2001, Jonathan FAULL

Director of DG-Press (Press and Communication) Spokesperson for President Prodi 
Antonio Vitorino, Commission for (2001-2004)

Justice, Home Affairs and Communication

2004-2009

President José Manuel Durão Barroso (Nov. 2004 -

Nov. 2009)

INFO-COM : Margot WALLSTRÖM, first Vice-President, Institutional Relations and Communication Strategy

\section{Since 2009}

President José Manuel Durão Barroso (Nov. 2009 -)

INFO-COM : Viviane Reding, Vice-president Justice, Fundamental Rights, and Citizenship
2003, Jorge DE OLIVEIRA E SOUSA

Director of DG-Press

2004, Colette LE BAIL

Director of DG-Press

2005, Panayotis CARVOUNIS

Director of DG-Press

2006-2011, Claus SORENSEN

Director-General DG Communication

2011-, G. PAULGER

Director-General DG Communication 
Accardo Alain, Journalistes au quotidien. Outils pour une socioanalyse des pratiques journalistiques, Bordeaux, Le Mascaret, 1995,

Aldrin Philippe, "L'Union européenne face à l'opinion. Construction et usages politiques de l'opinion comme problème communautaire "I, Savoir/Agir, 7, mars 2009.

Aldrin Philippe, Utard Jean-Michel, "The ambivalent politicisation of European communication. Genesis of the controversies and institutional frictions surrounding the 2006 White Paper "), GSPE Working Papers, 10/2008

Anderson, Peter J., McLeod Aileen, "The Great Non-communicator? The Mass Communication Deficit of the European Parliament and Its Press Directorate ", Journal of Common Market Studies, 42 (5).

Bailey Frederick, Les règles du jeu politique. Une étude anthropologique, Paris, Presses Universitaires de France, 1971.

Baisnée Olivier, Marchetti Dominique, «Euronews, un laboratoire de la production de l'information européenne' "), Cultures et Conflits, 38-39, 2000, pp.121-152.

Baisnée Olivier, "Can political journalism exist at the EU level ? " in R. Kuhn et E. Neveu (eds.), Political Journalism, Londres, Routledge, 2002.

Baisnée Olivier, Frinault Thomas, « Who cares about the EU ? » Les medias français et I'Europe in Costa Olivier et Magnette Paul (dirs.) Une Europe des Elites?, Bruxelles, Éditions de l'Université de Bruxelles, 2007.

Balandier Georges, "Ethnologie, anthropologie, sociologie ", in Boudon Raymond et al. (dir.), Sciences et théorie de l'opinion publique, Paris, Retz, 1981.

Bastin Gilles, Les professionnels de l'information européenne à Bruxelles. Sociologie d'un monde de l'information (territoires, carrières, dispositifs), Thèse de sociologie, Département de sciences sociales, École Normale Supérieure de Cachan, 2003.

Becker Howard, Les mondes de l'art, Paris, Flammarion, 1988.

Clerca (de) Willy, Réflexion sur la politique d'information et de communication de la Communauté européenne, Bruxelles, édité par la Commission européenne, 1993.

Collowald Paul, "La "Trajectoire" Strasbourg - Luxembourg - Bruxelles », in Dasseto Felice, Dumoulin Michel (dir.), Naissance et développement de l'information européenne, Berne, Peter Lang, 1993.

Commission européenne, Livre blanc sur la gouvernance européenne, Bruxelles, édité par la Commission européenne, 2001 [COM(2001) 428 final].

Commission européenne, Livre blanc sur une politique de communication européenne, Bruxelles, édité par la Commission européenne, 2006 [COM(2001) 428 final].

Commission européenne, Contribution de la Commission à la période de réflexion et au-delà. Le Plan D, comme Démocratie, Dialogue et Débat, Luxembourg, OPCE, 2005b.

Commission européenne, Plan d'action relatif à l'amélioration de la communication sur l'Europe, Bruxelles, édité par la Commission européenne, (juillet) $2005 a$

Commission européenne, Communiquer sur l'Europe par l'internet. Faire participer les citoyens, Bruxelles, édité par la Commission européenne, (décembre) 2007 [SEC/2007/1742]

Commission européenne, Conseil européen et Parlement européen, déclaration commune : "Communiquer l'Europe en partenariat 》, (octobre) 2008 [IP/08/1568]

Costa Olivier et Magnette Paul (dirs.) Une Europe des Elites?, Bruxelles, Éditions de I'Université de Bruxelles, 2007. 
Cram Laura, «The European Commission as a Multi-Organisation : Social Policy and IT Policy in the EU ॥, Journal of European Public Policy, 1 (2), 1994.

Dacheux, Éric, L'impossible défi. La politique de communication de I'Union européenne, Paris, CNRS Éditions, 2004.

David Marquand, Parliament for Europe, Londres, Cape, 1979.

De Swaan Abram, "The European Void: The democratic deficit as a Cultural Deficiency ", , in Fossum john erik, Schlesinger Philip, The European Union and the Public Sphere: A communicative space in the making?, Londres, Routledge 2007.

Dubar Claude, La socialisation. Construction des identités sociales et professionnelles, Paris, Armand Colin, 1997 (rééd.).

Duchesne Sophie, Muller Pierre, "Représentations croisées de l'État et des citoyens » in Favre Pierre, Hayward Jack, Schemeil Yves (dir.), Être gouverné. Ełudes en I'honneur de Jean Leca, Paris, Presses de Sciences Po, 2003

Dumoulin Michel, «Quelle politique de l'information? », in Dumoulin Michel (dir.), La Commission européenne, 1958-1972. Histoire et mémoires d'une institution, Bruxelles, Éd. De la Commission européenne, 2007.

Foret François, Légitimer l'Europe. Pouvoir et symbolique à l'ère de la gouvernance, Paris, Presses de Sciences Po, 2008,

Georgakakis Didier, "La démission de la Commission européenne : scandale et tournant institutionnel (octobre 1998 -mars 1999) 1), Cultures \& Conflits, 38-39, 2000.

Georgakakis Didier, Les métiers de l'Europe politique. Acteurs et professionnalisations de l'Union européenne, Strasbourg, Presses Universitaires de Strasbourg, 2002.

Georgakakis Didier, de Lassalle Marine, (dir.), La nouvelle gouvernance européenne, Strasbourg, PUS, 2007a.

Georgakakis Didier, de Lassalle Marine, "Genèse et structure d'un capital institutionnel européen. Les très hauts fonctionnaires de la Commission européenne II, Actes de la recherche en sciences sociales, 166-167, 2007b, p. 3853.

Hughes Everett, Le regard sociologique. Essais choisis, Paris, Éd. de l'EHESS, 1996.

Joana Jean, Smith Andy, Les commissaires européens. Technocrates, diplomates ou politiques?, Paris, Presses de Sciences Po, 2002

Jobert Bruno, Muller Pierre, L'Etat en action. Politiques publiques et corporatismes, Paris, Presses Universitaires de France, 1987.

Kingdon John, Agendas, alternatives, and Public Policies, Boston, Little Brown, 1984. Lagroye Jacques et al., Sociologie politique, Paris, Dalloz - Presses de la FNSP, 2002.

Lelu Agathe, 2000, L'action européiste de l'Agence Europe à travers les archives d'Emanuele Gazzo, Mémoire de Maîtrise d'Histoire contemporaine, Université Paris 1.

Magnette Paul, «L'Union européenne en quête d'un principe de légitimité », in Eric Dacheux (dir.), L'Europe qui se construit. Réflexions sur l'espace public européen, Saint-Etienne, PUS, 2003.

Manin Bernard, Principes du gouvernement représentatif, Paris, ChampsFlammarion, 1995.

Marchetti Dominique, (dir.), En quête d'Europe. Medias européens et médiatisation de l'Europe, Rennes, Presses universitaires de Rennes, 2004

Memmi Dominique, "Rendre puissant. De quelques postures (de communicateurs) au service de la domination $"$, in La Communication politique, Paris, PUF-CURAPP, 1991.

Meyer Christopher, «Political Legitimacy and the Invisibility of Politics: Exploring the European Union's Communication Deficit I, Journal of Common Market Studies, 37 (4), 1999.

Molotch Harvey, Lester Marylin, "Les usages stratégiques des événements: a promotion et le montage des nouvelles ", Padioleau Jean Gustave, L'Opinion 
publique: examen critique, nouvelles directions, Paris/La Haye/New York, Mouton/EHESS, 1981.

Negt Oskar, L'espace public oppositionnel, Paris, Payot, 2007.

Parlement européen, 1986, Rapport sur la politique d'information de la Communauté européenne (rapporteur : Gianni Baget Bozzo), A 2-111/86.

Parlement européen, Rapport de la commission de la culture et de l'éducation du Parlement européen sur le Livre blanc sur une politique de communication européenne (octobre) 2006.

Parlement européen, Rapport sur la politique d'information de la Communauté européenne (rapporteur : Gianni Baget Bozzo), 1986 (A-2-111/86).

Pierson Paul, "The Path to European Integration. A Historical Institutionalist Analysis ", Comparative Political Studies, 29 (2), 1996.

Rabier Jacques René, "La naissance d'une politique d'information sur la Communauté européenne (1952"1967) ", in Felice Dassetto, Michel Dumoulin (dir.), Naissance et développement de l'information européenne, Berne, Peter Lang, 1993.

Robert Cécile, Vauchez Antoine, "L'Académie européenne Savoirs, experts et savants dans le gouvernement de l'Europe "), Politix - Sciences sociales du politique, 89, 2010.

Sabatier Paul A., "The advocacy coalition framework: Revisions and relevance for Europe \#, Journal of European public policy, 5(1), 1998.

Schlesinger Philip, "The Babel of Europe? An Essay on Networks and Communicative Spaces ॥, ARENA Working Paper, 22, 2003.

Schmitter Philippe, Imagining the future of the Euro-polity with the help of new concepts, in Marks Garry (ed.), Governance in the European Union, London, Sage, 1996

Smith Andy, Le gouvernement de l'Union européenne. Une sociologie politique, Paris, LGDJ, 2004.

Stevens Anne, Stevens Handley, Brussels Bureaucrats? The Administration of the European Union, Londres, Palgrave Macmillan, 2001.

Tumber Howard "Marketing Maastricht: The EU and News Management », Media, Culture Society, 17, 1995.

Weber Max, Le savant et le politique, Paris, La Découverte, 2003 (1919).

Wright Sue, Community and Communication: the role of language in nation building and European integration, Clevedon Multilingual Matters, 2000. 